\title{
Examining the Effects of Tactical Procurement Practices on Service Delivery
}

\author{
Peter W. Obanda ${ }^{1}$, Samuel Pule ${ }^{2 *}$, Brian Aturinda ${ }^{3}$ \\ ${ }^{1}$ Senior Lecturer, Department of Procurement \& Marketing, Kyambogo University, Uganda \\ ${ }^{2}$ Lecturer, Department of Procurement \& Logistics, Victoria University Uganda \\ ${ }^{3}$ Senior Procurement Officer, Rakai District Local Government, Uganda
}

*Corresponding Author: Samuel Pule, Lecturer, Department of Procurement \& Logistics, Victoria University Uganda

\begin{abstract}
The study was centered on tactical procurement management and service delivery using a case of Rakai District. The study used three objectives, that is; to examine the effect of specification on service delivery in Rakai District Local Government, to evaluate the effect of selection on service delivery in Rakai District Local Government and to establish the relationship between contract award and service delivery in Rakai District Local Government. A cross-sectional research design was used for the study since data was collected as single point in time and this enabled the researchers to collect detailed and in-depth data from the respondents. The researchers used questionnaire and interview guide to collect data from the respondents and 58 respondents formed the sample size of the study. The findings of the study indicated that there is a strong positive linear relationship between specification, selection and contract award and service delivery $(r$ $=.901)$, specification, selection and contract award account for $81.2 \%$ variance of service delivery. In addition the coefficients of each tactical procurement management indicators show that Specification, selection and contract award significantly affect service delivery $(p<.05)$. Specification most affects service delivery $(t=4.454)$ followed by selection $(t=3.324)$ and contract award $(t=2.967)$, respectively. The study recommends Public Procurement and Disposal Authority should eliminate all elements of corruption in public procurement and promote integrity in the procurement process. This will in turn lead to improvement service delivery.
\end{abstract}

Keywords: Tactical Procurement, Specification, Evaluation, Award of Contract, Service Delivery

\section{INTRODUCTION}

Public Procurement has always been a big part of the developing countries economy accounting for an estimated 9-13\% of the developing nations Gross Domestic Product (GDP) and it is therefore an area that needs attention if countries are to enhance service delivery [23]. Procurement managers and stakeholders in the Public Service serve institutions created and governed by a complex array of statutes, regulations, policies, and directives. They operate in an environment of increasingly intense scrutiny and accelerated changes driven by technology, program reviews, and public and political expectations for service improvements. These combined result into growing institutional complexity and risks. However [2001] observes that millions of dollars gets wasted due to inefficient and ineffective procurement structures, policies and procedures as well as failure to impose sanctions for violation of procurement rules thus resulting in poor service delivery. Public procurement is the acquisition of goods, services and works by a procuring entity using public funds.

In order to improve the management of public procurement, many countries have come up with procurement reforms. According to [32] the last decade of the twentieth century has witnessed the start of the global evolution in the public procurement. Nonetheless [33] asserts that challenges in public procurement go beyond procurement regulations to include procurement process, methods, organizational structure and work force. This assertion is supported by the [1], which asserts that non - compliance with the regulations is so high in Uganda. The same report estimates that more than Uganda Shillings 300 Billion (US Dollars 164million) is lost every year and this leads to poor service delivery. [14] Explain that poor service delivery is a problem not only in the third world countries but 
also evident in the countries in the European Union. [14] Further advances reasons for poor service delivery is explained by the tendency to avoid red tape involved in the procurement process. However,[28] asserts that the type of goods and services procured sometimes influences the degree of compliance with the procurement regulations. In Uganda the need for procurement reforms became urgent because of internal and external pressure given the fact that the Government was losing huge sums of money in poorly managed procurement processes that cost the tax payer a lot of money.

The procurement reforms that were recommended in 2001 in Uganda in the Country Procurement Assessment Report are; the abolition of the Central Tender Board; enactment of a Procurement Law [25]; establishment of a policy regulation body, the Public Procurement and Disposal of Assets Authority; establishment of Contract Committees and Procurement Units in procuring entities; harmonization of central and local government regulations; incorporation of procurement plans in sector investment programs; preparation of standard bidding documents, establishment of a procurement cadre in the civil service and restoration of professionalism in the procurement function. All procurements and disposals handled by public procuring and disposing entities (PDEs) are governed by the regulations in the [25]. These regulations specify procurement and disposal procedures that have to be followed by all persons involved in procurement and disposal processes in order to ensure fairness, transparency, competitiveness and non - discrimination to all potential providers of goods services and works [25]. When poor service delivery is mentioned, focus is on the unethical behavior of the procurement officers and other aspects of public procurement. However, not much focus has been placed on explaining why there is poor service delivery with public sector organizations in Uganda despite the fact that each year compliance reports produced by the Public Procurement and Disposal of Public Assets Authority report that there is poor service delivery.

In Uganda, some scholars have conducted research on unethical practices in public procurement but no comprehensive study has been carried out on tactical procurement management and service delivery. Moreover, there are no empirical studies that can be traced to explain why there is poor service delivery. [22] sought to explain the unethical behavior of public procurement officers using social cohesion, group think and ethical attitudes and established that these variables considerably contribute to explain the unethical procurement behavior of procurement officers in Uganda. [22] explained unethical procurement behavior using psychological climate, catharsis, organizational anomie, procurement planning behavior and psychological wellness. [4] measured professionalism variables and their implication to procurement outcomes in Uganda's public sector. [20]was conducted with the aim to establish the most corrupt central government ministry or local governments, sectors and ministries. Several authors have advanced theories explaining the prevalence of corruption in public [3], [24], [13] \&[29] among others. But none of the above authors explains why there is persistent poor service delivery and this is what the study sought to verify in order to fill this gap.

\subsection{Problems Statement}

Tactical procurement management is intended to foster the element of transparency, integrity, impartiality, probity, accuracy of information in the provision of services. However, what is happening in local governments is different. The whole tactical procurement process is overshadowed with inefficiency, corruption and disregard of fundamental "value for money" considerations. Despite the concerted efforts by government to enact enabling procurement laws [25] to enhance tactical procurement management as means to improve service delivery, the services being provided to the end users have remained disheartening [35]. According Procurement Audit Management report, 2012/2013 of Rakai District, since the enactment of procurement laws, cases of poor service delivery have increased with frequent reports of corruption, provision of sub - standard services, denying some consumers the relevant services, conflict of interest, lack of uniformity, theft and inflated prices. Therefore one wonders whether this is due specification, selection or during contract award. In the wake of these mentioned challenges, a need for an in-depth analysis of the tactical procurement management in Rakai District and how it may affect service delivery was deemed necessary.

\subsection{Research Objective}

This study aimed at establishing the effect of the tactical procurement functions on service delivery in Rakai District Local Government. To operationalise the general objective, the following specific objectives were formulated; (1)to examine the effect of specification on service delivery in Rakai 
District Local Government, (2) to evaluate the effect of selection on service delivery in Rakai District Local Government, and lastly, (3) to establish the relationship between contract award and service delivery in Rakai District Local Government.

\section{LITERATURE REVIEW}

\subsection{Theoretical Review}

Several theories have been adopted for this study and the researchers dealt more with institutional theory, principal agent theory and systems theory. There is no single and universally agreed definition of "institution" or "institutional theory". According to Scott (2004), institutions are composed of cultural-cognitive and regulative elements that, together with associated activities and resources give meaning to life. The author explains the three pillars of institutions as regulatory, normative and cultural cognitive. The regulatory pillar emphasizes the use of rules, laws and sanctions as enforcement mechanism, with expedience as basis for compliance. The normative pillar refers to norms (how things should be done) and values (the preferred or desirable), social obligation being the basis of compliance. The cultural-cognitive pillar rests on shared understanding (common beliefs, symbols, shared understanding). In Uganda, public procurement is guided by the [25], regulations and guidelines which are from time to time issued by the PPDA Authority only and which must complied with to the latter by all PDEs and providers to ensure efficient service delivery.

The principal agent theory explains that procurement managers in public sector play a relationship role. But his findings are based on the buyer/supplier relationship and the need of the buyer, as the principal, to minimize the risks posed by the agent. The author argued that procurement managers including all civil servants concerned with public procurement must play the agent role. Therefore procurement managers take on the role of agent for elected representatives. The principal-agency theory holds that shirking is likely to occur when there is some disagreement between policy makers and the bureaucracy. The democratic perspective focuses on responsiveness to citizens and their representatives [31]. However, [30] identifies this principal/agent relationship among the possible risks whereby procurement managers show apathy towards principale preferred outcomes or even overriding of the principals preferences thus resulting into poor service delivery.

The study also used systems theory which was developed by Ludwig Von Bertalanaffy in 1940. His thinking in this theory was based on an interdisciplinary approach which attempts to fit together different aspects of the organisation. Ludwig's theory specifically dealt with the complex nature in systems, and proposed a framework which an organization more specifically local governments can use to investigate any group of objects that work together to produce some result. Therefore systems theory was adopted to examine how tactical procurement affects service delivery in local governments. According to the theory, the system must function efficiently and any fault in a system can affect the whole functioning of the whole system (Harrison \& Sundern, 2000). Judged in analogous ways, this theory explains how tactical procurement in terms of specification, selection and contract award can have a direct bearing on cost control, quality of the service and timeliness of the services rendered (Ferguson \& James, 2005). It is therefore, imperative to note that in an organization there must be a system that must be followed in the tactical procurement to ensure efficient service delivery.

\subsection{Conceptual Review}

Tactical procurement was operationalized by three major variables, namely; (1) Specification development, (2) supplier selection, and (3) contract award. These influence service delivery as discussed below:

\subsubsection{Specification and Service Delivery}

A specification can be defined as a description of the physical or functional characteristics, or of the nature of a supply, service, or construction item; the requirements to be satisfied by a product, material, or process indicating, if appropriate, the procedures to determine whether the requirements are satisfied [11]. In local government's specification is a statement of the attributes of a product, process or service user departments' wishes to purchase, and consequently, which the supplier is expected to supply [18]. As far as practicable, it is desirable that the requirements be expressed numerically in terms of appropriate units together with their limits. However, it is not clear whether 
this is the case in Rakai District Local government as there are a lot of non-compliance with specifications made in the procurement process which hinders greatly service delivery.

The specification is an important step in the procurement process and is a key factor in ensuring best value for money and the most sustainable outcome [3]. Simply, a specification is a description of the product or service required, reflecting the organization's sustainability demands. The quality of the specification determines the quality of the resulting supplier work. It is important to resist the temptation to just take the specification that was used last time and issue that, if the local government do this it may be running a high risk of failure [14]. The specification may not reflect today's approach to this product or service or indeed new requirements. According to [25], local government must not just take the specification of the specific product they like and copy that out, competitor suppliers will see through this quickly. When writing the specification and the sustainability criteria within it, consideration should be focused on: the risk assessment which has undertaken; identify key success factors for the contract; consult the previous specification (if available); enquire with a range of suppliers and obtain their fact sheets/ approach; use all the above as a base to work from, do not reinvent the wheel, but equally don't take the quick option that may result in failure. Think carefully about what is really important to the people and what would cause problems if it went wrong. Taking all this into account then one can start to write the specification [6]. However, what is not known is whether all the above are taken into consideration when making specification in local governments yet such have a bearing on service delivery.

Specification is important to achieving maximum value for expenditures on services to be delivered and enables the entities to identify and address all relevant issues pertaining to a particular service requirement before they publicize their notices to potential suppliers of goods, works and services [4]. The [34] requires all local governments to "take reasonable steps to ensure that their resources are used effectively, efficiently and economically". Good financial management is the key to local service delivery. It is quite disturbing to note that most local governments are generally associated with the worst form of financial management. Corruption, financial mismanagement and non-compliance with financial legislation are common. Consequently, this result to poor performance thus the delivery of social services is compromised. A specification should be sufficiently detailed so that the product or service will fit the users requirements [16]. It should not be so explicit that it prevents negotiation or discourages buyers or suppliers from using their expertise to propose alternative solutions that may offer better value for money for the services rendered. Preparation of a specification should involve close communication between the user and the Procurement and Supply Chain Manager and, if required, assistance from technical experts in order to register good service delivery (Fisher, 2004). Involvement of potential suppliers may also be helpful in developing a specification. If supplier input is required it must not result in adoption of a specification that favours one particular supplier.

However, what is happening in local governments is different as there are alot of rigidity in the preparation of specifications. In most cases they are done without involving technical expertise from suppliers which can affect adversely service delivery. Therefore by conducting this study, the recommendations put will assist Rakai District local government to overcome this problem which can affect efficient service delivery. A set of precise and clear specifications is a prerequisite for bidders to respond realistically and competitively to the requirements of the purchaser without qualifying their bids [31]. In the context of International Competitive Bidding (ICB), the specifications must be drafted to permit the widest possible competition and, at the same time, present a clear statement of the required standards of workmanship, materials, and performance of the goods and services to be procured [18]. Only if this is done will the objectives of economy, efficiency, and fairness in procurement be realized, responsiveness of bids be ensured, and the subsequent task of bid evaluation facilitated [36]. However, the study would like to find out is whether the specifications made in local governments shows all goods and materials to be incorporated in the goods be new, unused, and of the most recent or current models, and that they incorporate all recent improvements in design and materials unless provided for otherwise in the contract.

Specifications that properly identify the material and performance requirements are important for many reasons [37]. Good specifications encourage competition and enable the agency to purchase what it needs, when it needs it. When the specifications are clear, less time is spent addressing questions raised by bidders and issuing addendums, helping to keep procurement on schedule. Good specifications benefit bidders by clearly defining requirements, which in turn enables efficient use of 
resources when preparing and submitting bids, and ultimately supplying goods under contract. Nevertheless, it is not known whether specifications made in local governments are made on the basis for maintaining trust and integrity of all procurement systems. The overall purpose of a specification is to provide a basis for obtaining a good or service that can satisfy a particular need at an economical cost and to invite maximum reasonable competition [15]. To this end, specifications may not be unduly restrictive. By definition, a specification sets limits and thereby eliminates, or potentially eliminates, items that are outside the boundaries drawn. However, a specification should be written to encourage, not discourage, competition consistent with seeking overall economy for the purpose intended. A good specification should do four things: (1) Identify minimum requirements, (2) allow for a competitive bid, (3) list reproducible test methods to be used in testing for compliance with specifications, and (4) provide for an equitable award at the lowest possible cost.

Although Procurement has final responsibility for the competitiveness and suitability of specifications, procurement cannot initiate or prepare all specifications [15]. The size of staff necessary to do this would be prohibitive. Procurement serves as the primary activity involved in developing specifications for items purchased under indefinite quantity term contracts and definite quantity scheduled purchases [9]. The duty of procurement to promote both product and price competition requires that specifications be as non-restrictive as practicable, consistent with satisfying legitimate needs. Procurement is responsible for final editing of specifications, and ensuring clarity of language with jargon or in-house terminology. However, what is not clearly indicated by the authors is whether the procurement units in local governments assist and advise user departments in developing their specifications.

Specifications can be prepared in a number of ways [10]. Speaking generally, one is the specification that requires something unique, to be custom made or custom built, as is characteristic of construction or personal services contracts. The other group call for ready-made, off-the-shelf commercial items regularly available in the market place, as is characteristic of equipment, materials and supplies [9]. Within these broad groupings are more particular types, including: brand-name specifications; brandname-or-equal specifications; design specifications; performance specifications; and the Qualified Product List (QPL) [15]. Care must be taken in drafting specifications to ensure that they are not restrictive. In the specification of standards for equipment, materials, and workmanship, recognized international standards should be used as much as possible [36]. Where other particular standards are used, whether national standards of the Borrower's country or other standards, the specifications should state that equipment, materials, and workmanship that meet other authoritative standards, and which ensure at least a substantially equal quality than the standards mentioned, will also be acceptable.

\subsubsection{Supplier Selection and Service Delivery}

Supplier selection process is the screening process to identify the best responsible supplier of goods and services [9]. In the selection process, the focus in placed on competitive pricing, ability to meet specifications and standards, product and service quality, product yields and durability, reliable delivery methods, quality control methods and practices, technical abilities and leadership, ability to provide niche or unique product offering and/or design concept, financial stability and credit strength, compatibility with existing products, adequate distribution/warehousing facilities and resources, spare parts availability, warranty, insurance, and bonding provisions, proven performance and experience (quality references in and out of the industry preferred) and sales/service support resources available during prime hours of the business. However, what the study wants to find out is whether all the above are considered in selection process in Rakai District, since there still complaints from people about service delivery. Supplier selection is a multi-criteria decision making problem which includes both qualitative and quantitative factors. In order to select the best suppliers it is necessary to make a trade-off between these tangible and intangible factors some of which may conflict and thus affect service delivery. The majority of previous supplier selection techniques do not consider strategic perspective. Besides, uncertainty is one of the most important obstacles in supplier selection. Further researches in 2001 identified four stages in supplier selection problem consisting of problem formulation, formulation of criteria, qualification and final selection. In that study was stated that the majority of authors have focused on final selection stage [5]. In 2004, some previously published SSP models were challenged on a comparative basis to evaluate their relative efficiency considering their total cost of ownership [7]. Also a model was presented a framework for assessing the flexibility of a 
supply chain including the flexibility of product delivery system, production system, product development and supply system [26].

In local governments, the selection procedure is part of the public procurement reform initiated in 2002, which is supposed to be followed by all government departments and agencies to ensure transparency and accountability. However, what is not clearly indicated in the PPDA Act is whether the selection process is transparent. Sometime selections are made when the Tactical procurement management is already made and this in most cases done to make the whole process transparent yet contracts are already awarded to their favorite suppliers and this can affect adversely the service delivery in case a tender is awarded to a supplier without experience when the contract committee expects some gains in the end. Therefore, by conducting this study such loopholes will be highlighted in order to fill the knowledge gap. [3] argues that selection for highest bidders is one of the primary functions of procurement with a potential to contribute to the success of local government operations and improved service delivery. It is a function that sets in motion the entire acquisition/procurement process of acquiring services in local governments. But what the author failed to state is the element of transparency the selection process since cases of corruption have been reported but nothing has been done to enhance efficient service delivery which this study is will bring out.In the selection process, local governments may also maintain a comprehensive list of prospective bidders or offerors, and provide notices directly to those on the list.A comprehensive solicitation effort helps to ensure that the largest possible pool of potential vendors is made aware of the local governments' needs. It is upon the local governments to weigh the cost of using additional forms of media against the potential savings from increased competition.

Supplier selection is in most cases done according to PPDA regulations, sometimes non adherence to set rules and regulations are violated. Individuals are called to express their interest'. This is an initial stage of the tactical procurement process that helps the local government to see who's interested in bidding and draw up a short-list of possible suppliers. Firms may be asked for information about their finances and experience, or references from previous clients. Evaluating the suitability of potential suppliers to meet the needs of the local governments is normally undertaken after making an advert. This is the most efficient method of assessing suitability to meet the required criteria and is carried out prior to inviting them to tender. In large, complex contracts of long duration it is important to determine firstly, whether or not the organization will adopt a prequalification system, determine the qualifications or criteria and concurrently decide the tendering procedures. Public sector organizations' must comply with the requirements of the PPDA. These cover all aspects of the procurement of works, goods and service requirements and govern consideration of the procurement regulations to be adopted by the buying the local governments. The PPDA also set out the rules covering the procurement procedure to be followed and the permitted criteria for selecting (or excluding) suppliers invited to tender under the restricted and negotiated procedures and the contract award criteria. However there are a number of themes which could be used to measure supplier performance which the authors did not highlight such as: product quality - Mean Time Between Failure (MTBF), Mean Time to Repair (MTTR), percentage of delivery rejects, warranty claims, service quality using Service Level Agreements (SLA) - call-out time, customer service response time, performance against agreed delivery, lead times, relationship Management

\subsubsection{Contract Awarding and Service Delivery}

The contract award stage comprises of a number of important aspects; communicating the award to the successful tenderer, notifying the unsuccessful tenderers, debriefing unsuccessful tenderers and, in the case of contracts awarded under PPDA laws by public sector organisations, publishing a contract award. As will be seen, it is also useful for the procurement organization to conduct a debriefing of the successful tenderer. This stage should also include activities such as: ensuring that all relevant parties are aware of their roles and responsibilities in the immediate; implementation and transition process; checking that the agreed processes for contract management are in place by all the parties; that knowledge transfer from the procurement or project team (which may not have included members of the contracts management team) to the contracts management team takes place to ensure successful management of the contract; that, where necessary, the continuity plans for the seamless transition of the service from one contractor to the new contractor will be carried out as agreed. 
One of the goals of seeking competition is to foster honest competition to enable your government to obtain quality commodities and services at the lowest possible cost. Seeking competition also guards against favoritism, extravagance and fraud, while allowing interested vendors a fair and equal opportunity to compete. Organizations that embrace the goals of seeking competition can realize both monetary benefits and product satisfaction from the time, effort and resources required to conduct statutorily required competition. To realize these benefits fully, procurement officials need to be knowledgeable about the requirements of competitive bidding and competitive offerings (i.e., "best value" awards). Contracting out, at the local government level, is believed to be one of the principle areas where corruption in Uganda takes place [20]. Corruption is disastrous to the sound functioning of any government department. Corruption has been an intractable problem in many developing countries; especially where it has become systematic to the point where many in government have a stake. It diverts decision-making and the provision of services from those who need them to those who can afford them. Hence, the importance of ensuring that contracts are awarded to the lowest bidders cannot be over emphasized, as this would in no doubt promote service delivery.

[18] came up with some important service delivery improvement slogans. He said, "he who fails to plan for service delivery, plans to fail delivering services to the public. And if it cannot be measured, it cannot be improved. If we only plan to comply with regulations, we are not managers, we are robots. What we plan we must implement. What we implement, we must monitor. We should not be afraid to ask the customer (citizens). They really do know best what they need and what they get." A critical analysis of the above means that service users need to be involved from the outset of the Tactical procurement management. Without the meaningful involvement of service users, the contracting out of services can seem at odds with the personalization agenda, which promotes user choice and control. Often there should be service users involved on selection panels when contracting for a service [9]. In awarding of contracts for the provision of public services, it is a challenge to get the actual providers to be accountable for quality and efficiency as well as to have the resources and management authority to do the job well. The general feeling in the hotspots is that political leadership lacks responsiveness to issues raised by communities, incompetent, prone to corruption and with high degree of disregard for the communities which also compromises the delivery of services in local governments.

\section{RESEARCH METHODOLOGY}

\subsection{Study Design and Approach}

A cross-sectional design was used for this study because data was collected as single point in time and this enabled the researchers to collect detailed and in-depth data from the respondents. Both quantitative and qualitative approaches were employed in the study. This is because the quantitative approach allowed the researchers to gather data that was quantified while the qualitative approach allowed the researchers to gather data that could be quantified [19]. Combining numerical and textual information helped the researchers enrich the interpretation of findings of the study.

\subsection{Target Population, Sample Size and Sampling Techniques}

According to Human Resource Records of Rakai District for 2013, the district has 8 procurement officers, 9 departmental heads, 30 service providers and the study also focused on 22 regulating authorities thereby forming a population of 69 respondents. However, emphasis was also put on the Contract Committee responsible for tactical procurement process to ensure efficient service delivery in Rakai District local government. The sample size of the study was calculated basing on the [17] table. A total population of 69 had a composition of 30 service provider, 8 procurement officials, departmental heads 9 and regulating authorities 22 and it was from these, the samples was calculated and selected as shown in table below: -

Table3: Population, Sample Sizes and Sampling Techniques

\begin{tabular}{|l|l|l|l|}
\hline Category of Respondents & Population & Sample size & Sampling Technique \\
\hline procurement officials & 8 & 8 & Purposive Sampling \\
\hline Departmental heads & 9 & 9 & Purposive Sampling \\
\hline regulating authorities & 22 & 20 & Purposive Sampling \\
\hline Service providers & 30 & 28 & Simple Random Sampling \\
\hline Total & $\mathbf{6 9}$ & $\mathbf{6 5}$ & \\
\hline
\end{tabular}

Source: Field Data from Rakai District LG sampled using Krejcie and Morgan (1970) Sampling Method 
Two sampling techniques were used to select the sample size of the study. Procurement officers, departmental heads and regulating authorities were selected using purposive sampling technique. The purpose of using purposive sampling technique was to access confidential information relating tactical procurement and service delivery. This technique was used since the selected respondents have rich and deeper information and yet they are the center of ensuring value for money for the services rendered. Service providers were selected using simple random sampling technique. This technique was used to make sample selection without any prejudice and to enable every end user in Rakai District to have the same chance to be part of the study.

\subsection{Variable Measurement and Data Quality Control}

Questionnaires were accompanied with an ordinal measurement, which used the Likert scale to collect opinion data on the study variables using the five scales: $5=$ strongly agree; $4=$ agree; $3=$ undecided; $2=$ disagree; 1 = strongly disagree. Validity test were carried out prior to the administration of the research instruments. This was done in order to find out whether the questions are capable of capturing the intended data. Experts in research reviewed the questions to see whether they are capable of capturing the intended response. A Content Validity Index (CVI) was calculated in order to establish the validity of the research instrument.The results of CVI were .779 for specification and service delivery, 0.823 for selection and service delivery and .751 for contract award and service delivery. The results were greater than the recommended 0.70 by [2].This implied that the questionnaire was valid for data collection. Similarly, Reliability tests were also conducted using the Cronbach's Coefficient Alpha. The questionnaires were pre-tested to 15 respondents and the reliability results were computed using the Statistical Package for Social Scientists (SPSS). The results of alpha values were 0.711 for specification; .787 for selection; and lastly, .791 for contract award. These were greater than the recommended .70 and considered reliable as noted by [2].

\subsection{Data Analysis and Computation}

Quantitative data was coded and entered into a computer program known as a Statistical Package for Social Scientists (SPSS) for analysis [27]. Descriptive statistics was used to determine the distribution of respondents on the questions under each of the variables. Regression analysis was used to test the statistical significance of trends between specification, selection and contract award and service delivery and further to determine the extent to which tactical procurement affects service delivery. Qualitative data on the contrary, was analyzed using thematic method where data was collected from the field and grouped according to different themes based on research objectives. Further content analysis was also used by looking at the available content from the field and placing it under relevant themes under the objectives of the study. The main reason for using this type of analysis was to present issues as they existed on ground without subjecting the research findings to statistical tests. Judgment was made on the basis of highest percentages or otherwise depending on the facts on the ground. This involved content analysis, which was used to edit qualitative data and reorganize it into meaningful shorter sentences.

\section{FINDINGS OF THE STUDY}

\subsection{Tactical Procurement Management}

\subsubsection{Specification Development}

Result showed a high extent of specification management at Rakai District LG with an average mean of 4.14. This was due to high responses on the following issues; the specifications contain enough information for potential suppliers to design and cost the products or services they will offer (Mean = 4.01, SD 1.111), specifications are always written in performance terms, which focus on the function of the product or the output of the service required (Mean $=3.97$, SD 1.305), as specifications are developed considerations are made basing on quality and performance aspects of the goods and services of the contract (Mean $=3.81, \mathrm{SD} 1.115$ ), specifications provide equal opportunity for all potential suppliers to offer a product or service which satisfies the needs of the user (Mean $=3.79$, 1.107), specifications conform to relevant national, international standards and comply with any legal obligations (Mean $=3.73$, SD 1.021), specifications are built around a description of what is to be achieved rather than a fixed description of exactly how it should be done (Mean = 3.69, SD 1.105), and lastly, in the design of specifications, stakeholders' needs are taken into account (Mean $=2.01$, 
SD 1.09). The following qualitative Responses on the issue of specification development were also obtained:

Table4.1: Showing Qualitative Responses on Specification Development

\begin{tabular}{|c|c|c|}
\hline $\mathbf{S} / \mathbf{N}$ & Questions asked & Response \\
\hline 1 & $\begin{array}{l}\text { Are your procurement items } \\
\text { related time and again? Or } \\
\text { their instances when User } \\
\text { Departments request for } \\
\text { totally different items from } \\
\text { the usual ones? }\end{array}$ & $\begin{array}{l}\text { Things we want in most cases are the same and that means we have a } \\
\text { list we use because the district knows what it wants and that means not } \\
\text { everyone is given a chance to express statements of attributes of the } \\
\text { requirements we want and in rare cases we allow user departments to } \\
\text { express their requirement and we make an evaluation not to create a } \\
\text { mismatch between what is requested and supplier. }\end{array}$ \\
\hline 2 & $\begin{array}{l}\text { Which criteria doe you flow } \\
\text { when writing specification? } \\
\text { And what challenges do face } \\
\text { in writing these } \\
\text { specifications? }\end{array}$ & $\begin{array}{l}\text { Generally specifications are written in performance terms, which focus } \\
\text { on the function of the product or the output of the service required. } \\
\text { However, he noted that although this is done, staff in procurement unit, } \\
\text { violate these specification with the intension of defraud tax payers } \\
\text { money. Items procured, in some case do not meet the specifications } \\
\text { made and this cripples efforts to deliver the desired services. }\end{array}$ \\
\hline 3 & $\begin{array}{l}\text { Are your specifications } \\
\text { normally detailed to allow } \\
\text { supplier understand the } \\
\text { request of the organization? }\end{array}$ & $\begin{array}{l}\text { It is true that specifications contain enough information for potential } \\
\text { suppliers to design and cost the products or services they will offer. } \\
\text { But when it comes to delivery of services different things happen } \\
\text { because procurement unit staff connive with the suppliers and change } \\
\text { the items to be supplied and in the end poor quality items are procured } \\
\text { which affect adversely efforts to ensure efficient service delivery. }\end{array}$ \\
\hline 4 & $\begin{array}{l}\text { Do the specifications drafted } \\
\text { conform to national and/ } \\
\text { international standards? }\end{array}$ & $\begin{array}{l}\text { Even though specifications conform to relevant national, international } \\
\text { standards and comply with any legal obligations. There is a lot of non- } \\
\text { compliance with such laws and this affect negatively service delivery. }\end{array}$ \\
\hline 5 & $\begin{array}{l}\text { When drafting these } \\
\text { specifications, do take care of } \\
\text { all stakeholders needs? }\end{array}$ & $\begin{array}{l}\text { Not every stakeholder's needs are taken into account when designing } \\
\text { the specification of materials, products or works because this can } \\
\text { create conflict of interest. If all stakeholders' needs are considered, it } \\
\text { can result into wrong (ambiguous) specification. }\end{array}$ \\
\hline
\end{tabular}

Source: Field Data (2015)

\subsubsection{Supplier Selection}

Findings revealed a moderate extent of supplier selection practices in Rakai District LG (average mean $=3.63$ ). This was attributed to moderate responses on the issues of; financial stability and effective business continuity plans and processes are central in supplier selection (Mean $=4.01$, SD 0.967), ability to meet requirements are very important in supplier selection (Mean $=3.98$, SD 1.008), compliance with applicable laws and diligent in ethical business practices are key factors in selection process (Mean $=3.95$, SD 1.268), emphasis is put on excellent track record with quality and delivery through deployment of mature quality management systems (Mean $=3.94$, SD 0.988), skills and willingness to continuously improve reliability with an effective corrective and preventive action system are generally considered in selection criteria (Mean $=3.59$, SD 1.004), lowest total cost competitive pricing is considered in selecting suppliers (mean $=3.54$, SD 1.204), the supplier with the highest total score should be the most attractive supplier (Mean $=3.44$, SD 1.318), and lastly, supplier selection constraints are unbreakable rules in the supplier selection process (Mean $=2.6$, SD 1.25). Qualitative data concerning supplier selection was also obtained as indicated in table 4.1 below:

Table4.2: Showing Qualitative Responses on Supplier Selection

\begin{tabular}{|l|l|l|}
\hline S/N & Questions asked & Responses \\
\hline 1 & $\begin{array}{l}\text { The Auditor General Report (2013) } \\
\text { highlights many districts to be } \\
\text { associated with corruption; do you } \\
\text { think Rakai falls in this bracket? And } \\
\text { if yes, why do you think so? }\end{array}$ & $\begin{array}{l}\text { This ingreement with what the one officer in procurement } \\
\text { snit highlighted that there are lot of favoritism in the selection of } \\
\text { cost bidder and sometimes it not. }\end{array}$ \\
\hline 2 & $\begin{array}{l}\text { What prequisite do you put forth in } \\
\text { order to select effective suppliers? }\end{array}$ & $\begin{array}{l}\text { We generally consider cost, quality, delivery and flexibility } \\
\text { according to the ability of the supplier in the selection process } \\
\text { and this is the most important aspect. Otherwise if you neglect } \\
\text { the supplier's ability to meet requirement, everything can go } \\
\text { wrong }\end{array}$ \\
\hline 3 & How can you select a supplier & A comparison is always made to identify which supplier is in \\
\hline
\end{tabular}




\begin{tabular}{|c|c|c|}
\hline & $\begin{array}{l}\text { without verifying his or her financial } \\
\text { position? }\end{array}$ & $\begin{array}{l}\text { better financial position. The reason we do this is to ensure } \\
\text { continuity in the business. }\end{array}$ \\
\hline 4 & $\begin{array}{l}\text { Given the current procurement } \\
\text { scandals on Rakai District; how do } \\
\text { plan to uphold ethics and legal } \\
\text { compliance as a District? }\end{array}$ & $\begin{array}{l}\text { Central to the whole of tactical procurement management is } \\
\text { compliance with applicable laws. However, Rakai District is still } \\
\text { experiencing scandals due to unethical behavior and trust in } \\
\text { selection process is lost. Some scandals are directly or indirectly } \\
\text { linked to procurement and this has resulted to a greater emphasis } \\
\text { on ethics and accountability training for both employees and } \\
\text { elected officials. }\end{array}$ \\
\hline 5 & $\begin{array}{l}\text { What do take on the issue of skill } \\
\text { and willingness among suppliers as a } \\
\text { key driver to successful contract } \\
\text { implementation }\end{array}$ & $\begin{array}{l}\text { It is important to focus on the skills and willingness to } \\
\text { continuously improve reliability but the problem of nepotism in } \\
\text { the selection and lack of integrity makes the whole process } \\
\text { 'rotten' and requires a savoir to enhance service delivery. }\end{array}$ \\
\hline 6 & $\begin{array}{l}\text { There are so many qualities and } \\
\text { attributes which are focused in } \\
\text { selecting the right supplier; what do } \\
\text { you think is the best quality to } \\
\text { consider? }\end{array}$ & $\begin{array}{l}\text { Of course, the quality management dimension is normally given a } \\
\text { lion's share, followed by the prices issue and other attributes } \\
\text { come next. }\end{array}$ \\
\hline 7 & $\begin{array}{l}\text { Supplier selection rules are clear in } \\
\text { the PPDA Act; do you think the } \\
\text { Districts uphold them always? }\end{array}$ & $\begin{array}{l}\text { Yes, in most cases there are upheld, though sometimes especially } \\
\text { in emergencies we may not necessary follow given the prevailing } \\
\text { conditions. }\end{array}$ \\
\hline
\end{tabular}

Source: Field Data (2015)

\subsubsection{Contract Award}

A moderate extent of observing contract award principles were noted with an average mean of 3.50 . this was due to high responses on the following issues: contracts are awarded to people who have bribed the contract committee (4.05, SD 1.11), the process of awarding contracts is not transparent (4.04, SD 0.321), contractual deliverables are completed within the agreed time (Mean $=3.79$, SD 0.907), contracts given out do not result into value for money (3.72, SD 1.296), contract award is determined basing on price and not-price factors (3.58, SD 1.256), in awarding contracts roles and responsibilities are communicated (3.58, SD 1.153), contract award is something not communicated to successful tenderer in time (3.06, SD 1.174), contracts are awarded to the lowest responsible bidder (2.99, SD 1.414), and lastly, to award contracts considerations are made basing on the people's demands (2.79, SD 1.18). Similarly, qualitative responses on the issue of contract award were retrieved as follow:

Table4.3: Showing Qualitative Responses on Contract Award

\begin{tabular}{|l|l|l|l|}
\hline S/N & \multicolumn{1}{|c|}{ Questions asked } & \multicolumn{1}{c|}{ Responses } \\
\hline 1 & $\begin{array}{l}\text { Are contractual deliverables } \\
\text { always completed in time by } \\
\text { suppliers? }\end{array}$ & $\begin{array}{l}\text { It is rare for contractual deliverables to be completed within the } \\
\text { agreed time. Sometimes unforeseen circumstance may cause delaysand } \\
\text { this may prove to be costly and thus affect negatively service delivery. }\end{array}$ \\
\hline 2 & $\begin{array}{l}\text { Is the procurement unit } \\
\text { transparent and ethical is } \\
\text { performing its duties? And is } \\
\text { competition upheld at all } \\
\text { times? }\end{array}$ & $\begin{array}{l}\text { In Rakai, there is a problem of integrity. Contracts are not given on } \\
\text { air ground. There is little and sometimes no competition permitted } \\
\text { and thus sub-standard works, products and services are procured and } \\
\text { this affects negatively service delivery. }\end{array}$ \\
\hline 3 & $\begin{array}{l}\text { What factors are normally } \\
\text { taken into account in suppler } \\
\text { selection? And how does the } \\
\text { entity mitigate against fraud } \\
\text { within the procurement } \\
\text { process? }\end{array}$ & $\begin{array}{l}\text { One of the goals of getting the best suppliers is to look at price factors } \\
\text { and other factors such honest and quality commodities and services at } \\
\text { favoritism and fraud. By looking at price and not price factor it allows } \\
\text { interested vendors a fair and equal opportunity to compete. }\end{array}$ \\
\hline 4 & $\begin{array}{l}\text { Are key Actors consulted } \\
\text { when awarding procurement } \\
\text { contracts? }\end{array}$ & $\begin{array}{l}\text { People are not consulted when awarding contracts and thus the } \\
\text { outcomes of such are not known to people. } \\
\text { level do you make of the } \\
\text { economy in service delivery } \\
\text { among suppliers at the } \\
\text { District? }\end{array}$ & $\begin{array}{l}\text { There is little or no element of efficiency in the service rendered, } \\
\text { contracts awarded are not effective and they are not economic and } \\
\text { these are the major components for value for money. }\end{array}$ \\
\hline 5
\end{tabular}




\begin{tabular}{|l|l|l|l|}
\hline 6 & $\begin{array}{l}\text { Do think when people } \\
\text { understand their roles and } \\
\text { responsibilities, it improves } \\
\text { contract management? }\end{array}$ & $\begin{array}{l}\text { It important for the parties to understand their roles and } \\
\text { responsibilities to ensure successful management of the contract and } \\
\text { continuity plans as agreed. }\end{array}$ \\
\hline
\end{tabular}

Source: Field Data (2015)

\subsection{Service Delivery}

Results indicated low levels of service delivery management in Rakai District LG generally (average mean $=3.31$ ). This was attributed to very high responses on the issue of; the quality of services the district get from the contractors are sub standards to meet the district needs (4.36, SD 1.151), responsiveness in service delivery is attained when the expected benefits from the contract and value for money are being achieved (3.97, SD 1.24), people have a greater awareness of the services received and the additional services that can be provided (3.63, SD 1.295), the contracts awarded to the contractors results into efficient service delivery (3.56, SD 1.24), there are few complaints from contractors and the district about the services offered (3.34, SD 1.301), the arrangement for service delivery continue to be satisfactory to both the district and the contractor (3.10, SD 1.29), contract deliverable are always on time as expected by the district (2.34, SD 1.27), and lastly, there is high element of reliability in service deliverables in Rakai district (2.2, SD 1.31). The study also extracted the following qualitative result in order to judge people's opinion on as far as service delivery was concerned:

Table4.4: Showing Qualitative Responses on Service Delivery

\begin{tabular}{|c|c|c|}
\hline $\mathbf{S} / \mathbf{N}$ & Questions asked & Response \\
\hline 1 & $\begin{array}{l}\text { Do you think there is reliable } \\
\text { service delivery now in Rakai } \\
\text { District? Or No what do think } \\
\text { should be done? }\end{array}$ & $\begin{array}{l}\text { The element of reliability in service deliverables is still a big challenge } \\
\text { in Rakai District. Sometimes services are good and in other times are } \\
\text { sub-standard, but the district is working hard to ensure that the } \\
\text { element of reliability is taken as a serious issue when it comes to the } \\
\text { delivery of services. }\end{array}$ \\
\hline 2 & $\begin{array}{l}\text { What is the status of contract } \\
\text { delivery management among } \\
\text { suppliers? And how do make } \\
\text { of the issue of integrity and } \\
\text { transparency among } \\
\text { contractors? }\end{array}$ & $\begin{array}{l}\text { Contract deliveryis continuously improving among suppliers. This is } \\
\text { because of the pressure the District has exerted on them. Further the } \\
\text { issue of integrity and transparency in the work of the contractors is } \\
\text { alsodeclining as many contractors are producingless substandard } \\
\text { items/ projects. }\end{array}$ \\
\hline 3 & $\begin{array}{l}\text { Is the procurement unit of } \\
\text { your organization ethically } \\
\text { presented? }\end{array}$ & $\begin{array}{l}\text { The procurement and disposal unit is corrupt and not transparent and } \\
\text { people do not make accountability of how they have used the district } \\
\text { resource. Contracts are awarded to suppliers having political } \\
\text { influence and in the end people fail to get what they expect from the } \\
\text { district. }\end{array}$ \\
\hline 4 & $\begin{array}{l}\text { Do you agree that service } \\
\text { delivery is satisfactory both } \\
\text { the District and Contractors in } \\
\text { Rakai? }\end{array}$ & $\begin{array}{l}\text { It is not true that service delivery continue to be satisfactory to both } \\
\text { the district and the contractor, Rakai District some problems to } \\
\text { register success stories. The major problem rotates around lack of } \\
\text { trust, commitment, communication and resources. When such are not } \\
\text { there then there is a problem in delivering better services. There is an } \\
\text { urgent need to make proper arrangement for service delivery continue } \\
\text { to be satisfactory to both the district and the contractor. }\end{array}$ \\
\hline 5 & $\begin{array}{l}\text { Does the Procurement Unit } \\
\text { conduct seminars and training } \\
\text { workshops to stakeholders in } \\
\text { order to improve service } \\
\text { delivery? }\end{array}$ & $\begin{array}{l}\text { Workshops and seminars are conducted and people exchange their } \\
\text { views and opinions about the services rendered and complaints are } \\
\text { taken for corrective action plan. }\end{array}$ \\
\hline
\end{tabular}

Source: Field Data (2015)

\subsection{Model Analysis of Tactical Procurement Management and Service Delivery}

\subsubsection{Correlations Analysis}

This section tested the relationship between tactical procurement management and service delivery in Rakai District. In order to test the relationship between the two variables, it was important to first make a pre-condition test for linearity as shown below: 


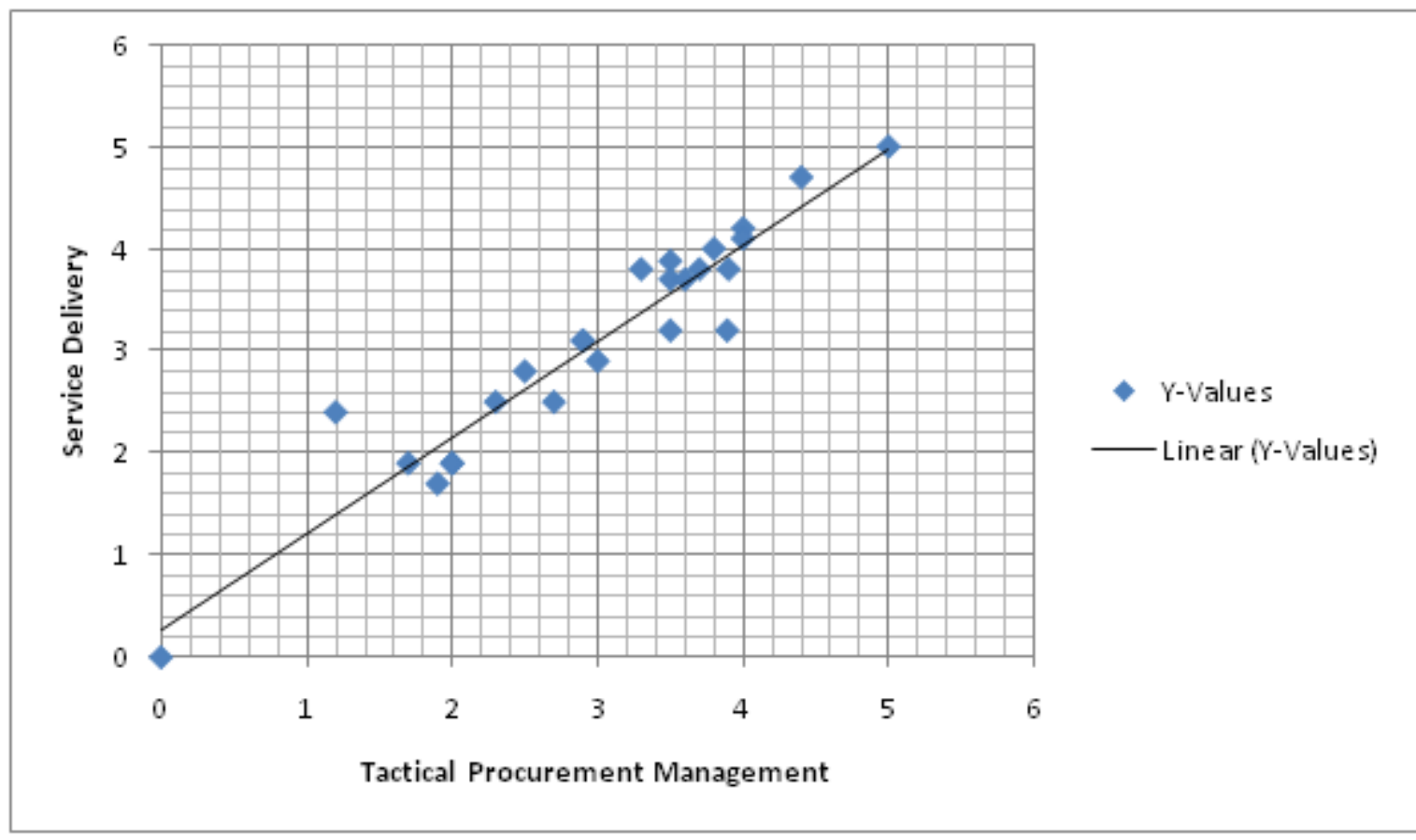

Figure1: Linear Relationship between Tactical Procurement \&Service Delivery

From figure I, the study revealed that there is a strong positive linear relationship between tactical procurement management and service delivery as determined by the closeness of points on the line of best fit and this led the study us to measure levels of prediction among variables as indicated in table 4.5, 4.6, and 4.7:

\subsubsection{Regression Analysis}

This section provides results on the influence of specification development, supplier selection, contract award on service delivery as indicated in Table 4.5, 4.6 and 4.7 below

Table 4.5: Model Summary

\begin{tabular}{|l|l|l|l|l|}
\hline \multicolumn{5}{|l|}{} \\
\hline Model & R & R Square $^{\mathrm{b}}$ & Adjusted rSquare & Std. Error of the Estimate \\
\hline 1 & $.901^{\mathrm{a}}$ & .812 & .791 & 4.31315 \\
\hline
\end{tabular}

Source: Field Data (2015)

From table 4.6.1, the study shows a strong influence of specification, selection, contract award on service delivery $\left(\mathrm{R}^{2}=.812\right)$, which implies that Tactical procurement highly determines service delivery in Rakai Local Government.

Table 4.7: Coefficients of Specification, Selection, Contract Award against Service Delivery

\begin{tabular}{|c|c|c|c|c|c|c|}
\hline \multirow{2}{*}{\multicolumn{2}{|c|}{ Model }} & \multicolumn{2}{|c|}{ Unstandardized Coefficients } & Standardized Coefficients & \multirow[t]{2}{*}{$\mathrm{T}$} & \multirow[t]{2}{*}{ Sig. } \\
\hline & & B & Std. Error & Beta & & \\
\hline \multirow[t]{3}{*}{1} & Specification & .342 & .051 & .571 & 4.454 & .000 \\
\hline & Selection & .297 & .045 & .262 & 3.324 & .008 \\
\hline & Contract award & .280 & .140 & .197 & 2.967 & .029 \\
\hline
\end{tabular}

Source: Field Data (2015)

From table 4.6.3 above, Specification most affects service delivery $\left(\mathrm{r}^{2}=.0342\right)$ followed by selection $\left(r^{2}=.297\right)$, and lastly, contract award $\left(r^{2}=.280\right)$, respectively.

\section{DisCUSSION OF RESUlTS}

\subsection{Specification and Service Delivery}

The findings indicated that specifications are built around a description of what is to be achieved rather than a fixed description of exactly how it should be done. This view was highlighted by [10] 
that specifications can be prepared in a number of ways. Speaking generally, one is the specification that requires something unique, to be custom made or custom built, as is characteristic of construction or personal services contracts. In the same vein, results showed that specifications are always written in performance terms, which focus on the function of the product or the output of the service required. More still, the study reflects that the specifications contain enough information for potential suppliers to design and cost the products or services they will offer. This is in agreement with [16] that specification should be sufficiently detailed so that the product or service will fit the user requirements. It should not be so explicit that it prevents negotiation or discourages buyers or suppliers from using their expertise to propose alternative solutions that may offer better value for money for the services rendered.[36]points out that care must be taken in drafting specifications to ensure that they are not restrictive. In the specification of standards for equipment, materials, and workmanship, recognized international standards should be used as much as possible. Where other particular standards are used, whether national standards of the Borrower's country or other standards, the specifications should state that equipment, materials, and workmanship that meet other authoritative standards, and which ensure at least a substantially equal quality than the standards mentioned, will also be acceptable.

Respondents also were with a view specifications providing equal opportunity for all potential suppliers to offer a product or service which satisfies the needs of the user. This view was supported by [12], that the preparation of a specification should involve close communication between the user and the Procurement and Supply Chain Manager and, if required, assistance from technical experts in order to register good service delivery. Involvement of potential suppliers may also be helpful in developing a specification. If supplier input is required it must not result in adoption of a specification that favors one particular supplier. To note further, majority responses disagree that in the design of specifications, stakeholders' needs are taken into account. It also found out that there is alot of rigidity in the preparation of specifications in local governments. In most cases they are done without involving technical expertise from suppliers which can affect adversely service delivery. It was also revealed that, specifications are developed must give sufficient considerations for quality and performance aspects of the goods and services of the contract. This is in agreement with [18], that the specifications must be drafted to permit the widest possible competition and, at the same time; present a clear statement of the required standards of workmanship, materials, and performance of the goods and services to be procured.

\subsection{Supplier Selection and Service Delivery}

It was found out that lowest total cost competitive pricing is considered in selecting suppliers. This is in agreement with [9], that in the selection process, the focus in placed on competitive pricing, ability to meet specifications and standards, product and service quality, product yields and durability, reliable delivery methods, quality control methods and practices, technical abilities and leadership, ability to provide niche or unique product offering and/or design concept, financial stability \& credit strength. Result also indicated that, ability to meet requirements is very important in supplier selection. In selection process, local governments may also maintain a comprehensive list of prospective bidders and provide notices directly to those on the list.A comprehensive solicitation effort helps to ensure that the largest possible pool of potential vendors is made aware of the local governments' needs. It is upon the local governments to weigh the cost of using additional forms of media against the potential savings from increased competition. In the same way, most responses were in agreement that financial stability and effective business continuity plans and processes are central in supplier selection. This is in line with [37], that firms may be asked for information about their finances and experience, or references from previous clients. Evaluating the suitability of potential suppliers to meet the needs of the local governments is normally undertaken after making an advert. This is the most efficient method of assessing suitability to meet the required criteria and is carried out prior to inviting them to tender

However, the study shows that compliance with applicable laws and diligent in ethical business practices are key factors in selection process. This is in line with the [20] that selection is in most cases done according to PPDA regulations, sometimes non adherence to set rules and regulations are violated. Individuals are called to express their interest'. This is an initial stage of the tactical procurement process that helps the local government to see who's interested in bidding and draw up a short-list of possible suppliers. To mention further, findings revealed that skills and willingness to continuously improve reliability with an effective corrective and preventive action system are 
generally considered in selection criteria. In the selection process, the focus in placed on competitive pricing, ability to meet specifications and standards, product and service quality, product yields and durability, reliable delivery methods, quality control methods and practices, technical abilities and leadership, ability to provide niche or unique product offering and/or design concept, financial stability \& credit strength, compatibility with existing products, adequate distribution/warehousing facilities and resources, spare parts availability, warranty, insurance, and bonding provisions, proven performance and experience

It was established that little emphasis is put on excellent track record with quality and delivery through deployment of mature quality management systems. In local governments, the selection procedure is part of the public procurement reform initiated in 2002, which is supposed to be followed by all government departments and agencies to ensure transparency and accountability. However, what is not clearly indicated in the PPDA Act is whether the selection process is transparent.Still to mention, it was established that, it is not to select a supplier with the highest total score, but rather one with the highest quality parameters. This view was averagely supported by [3] that selection for highest bidders is one of the primary functions of procurement with a potential to contribute to the success of local government operations and improved service delivery. It is a function that sets in motion the entire acquisition/procurement process of acquiring services in local governments. Thus supplier selection constraints are unbreakable rules in the supplier selection process

\subsection{Contract Award and Service Delivery}

It was established that the process of awarding contracts is not transparent and that contractual deliverables are not completed within the agreed time. One of the goals of seeking competition is to foster honest competition to enable your government to obtain quality commodities and services at the lowest possible cost. Seeking competition also guards against favoritism, extravagance and fraud, while allowing interested vendors a fair and equal opportunity to compete. The study further revealed that respondents were not sure with the test statement that contracts are awarded to the lowest responsible bidder. However, it was also established that when using competitive bidding, contracts are awarded to the "lowest responsible bidder" after public advertisement for sealed bids. As further discussed below, local governments may elect to award "purchase contracts," which exceed the monetary threshold, on the basis of "best value," as an alternative to awarding contracts to the "lowest responsible bidder There contract award is determined basing on price and not-price factors. More still, the study established that contract award is something not communicated to successful tenderer in time. The contract award stage comprises of a number of important aspects; communicating the award to the successful tenderer, notifying the unsuccessful tenderers, debriefing unsuccessful tenderers and, in the case of contracts awarded under PPDA laws by public sector organizations, publishing a contract award.

The study further revealed that respondents agreed with the test statement that contracts are awarded to people who have bribed the contract committee. This is in line with [20] that contracting out, at the local government level, is believed to be one of the principle areas where corruption in Uganda takes place. Corruption is disastrous to the sound functioning of any government department. Corruption has been an intractable problem in many developing countries; especially where it has become systematic to the point where many in government have a stake. It diverts decision-making and the provision of services from those who need them to those who can afford them [20]. Therefore the study as that respondents were indifferent as to whether to award contracts considerations are made basing on the people's demands and thus does not result value for money. Furthermore, the study reveals that respondents seem to agree that in awarding contracts roles and responsibilities are communicated. This stage should also include activities such as: ensuring that all relevant parties are aware of their roles and responsibilities in the immediate; implementation and transition process; checking that the agreed processes for contract management are in place by all the parties; that knowledge transfer from the procurement or project team (which may not have included members of the contracts management team) to the contracts management team takes place to ensure successful management of the contract; that, where necessary, the continuity plans for the seamless transition of the service from one contractor to the new contractor will be carried out as agreed.

\section{CONClusion}

The study was focused on tactical procurement management and service delivery. It was established that there is a strong positive linear relationship between specification, selection and contract award 
and service delivery $(\mathrm{r}=.901)$, specification, selection and contract award account for $81.2 \%$ variance of service delivery. In addition the coefficients of each tactical procurement management indicators show that Specification, selection and contract award significantly affect service delivery $(\mathrm{p}<.05)$. Specification most affects service delivery $(t=4.454)$ followed by supplier selection $(t=3.324)$ and contract award $(\mathrm{t}=2.967)$, respectively. It should therefore, stated that careful specification of the requirements needed by user department can lead to efficient service deliver. Further the selection process requires a great deal of planning preparation and time resourcefulness of the procurement unit and should be transparent to enhance efficient service delivery. Lastly, the awarding of contract should be done basing on the lowest responsible bidder and meet all the selection criteria.

\section{RECOMMENDATIONS}

Basing on the findings of the study, the following recommendations are made to the local governments and PDU in order to stimulate efficient service delivery.

- Rakai District Local Government should eliminate all elements of corruption in public procurement and promote integrity in the procurement process. This will in turn lead to improvement service delivery.

- Additionally, the Ministry of Local Governments should foster financial accountability by strengthening the internal controls in place. This can help local governments like Rakai District to overcome the challenges of corruption, theft and embezzlement of funds. It should be argued that poor financial accountability is central towards inefficient service delivery.

- The procurement and disposal unit of Rakai District should continuously be appraised to assess their strengths and weakness by oversight institutions such as PPDA and the Auditor General. This can iron out inefficiencies the public procurement since such oversight institutions ensure that there strict adherence procurement regulations and compliances with procurement procedures.

\section{REFERENCES}

[1] African Peer Review Mechanism [APRM] Country Review Report No. 7 on the Republic of Uganda, () 2009 APRM, Halfway House Midrand 1685, South Africa, The New Partnership for Africa's development

[2] Amin, M. E. (2005). Social science research: Conception, methodology and analysis. Makerere University.

[3] Basheka, B. C.(2009) Public procurement corruption and its implications on effective Service delivery in Uganda: An empirical study, International Journal of Procurement Management, Vol.2, No. 2, pp 415 - 440

[4] Basheka, B. C., \& Mugabira, M. I., (2008). Measuring professionalism variables and their implication to procurement outcomes in Uganda. In The 3rd International Public Procurement Conference Proceedings

[5] De Boer, L., Labro, E., \& Morlacchi, P. (2001). A review of methods supporting supplier selection. European Journal of Purchasing and Supply Management, 7(2), 75-89

[6] De-Boer, L., \& Telgen, J. (2006), Purchasing Practice in Dutch Municipalities, Journal of Supply Chain Management, Vol.34, No. 2, pp. $31-36$.

[7] Degraeve, Z., Labro, E., \& Roodhoofi, F. (2004). Total cost of ownership purchasing of a service: The case of airline selection at Alcatel Bell. European Journal of Operational Research, 156(1), 23-40.

[8] Donahue, J.E., (1989). The Privatisation Decision: Public Ends, Private Means, Basic Books, New York, NY

[9] Drinkwater, M., (2011). The impact of competitive tendering on social services and service users. Available from: http://www.communitycare.co.uk/2011/11/17/the-impact-of-competitive-tendering-onsocial-services-and-service-users/\#.U5N5wnaPCPo,(Accessed: 7 June, 2014).

[10] Evenett J. (2006) Can Developing Countries Benefit from Negotiations on Transparency in government procurement in Doha round? Accessed on 11 June 2014 at http://www.ycsg.yale.educ,www.evennet.com

[11] Eyaa, S., \& Oluka P., (2011). Explaining Non- Compliance in Public Procurement in Uganda. International Journal of Business and Social Science, Vol. 2 No. 11

[12] Fisher, E., (2004). The European Union in the Age of Accountability, Oxford Journal of Legal Studies, 24, 1: 495-515.

[13] Gratto, A., Preston, B., \& Snilsberg, T. (2002, December). Mitigating corruption in new public management. In Privatisation and Devolution Conference.

[14] Gelderman, Ghijsen, P.W., \& Brugman, M.J., (2006). Public Procurement and EU Tendering Directives Explaining Non-Compliance, International Journal of Public Sector Management, Vol. 19, No. 7, pp. 702 - 714. 
[15] Hefetz, A., \& Warner, M. E., (2011). Contracting or public delivery? The importance of service, market and management characteristics, Journal of Public Administration Research and Theory, mur006

[16] Hwang, H., \& Powell, W.W., (2009). The Rationalization of Charity: The influences of professionalism in the non-profit sector. Administrative Science Quarterly, 54(2): 268-298.

[17] Krejcie, R. V., \& Morgan, D. W. (1970). Determining sample size for research activities. Educ psychol meas.

[18] Lan, Z.G. Riley, L. \& Cayer, J. N. (2005). How can local Government Become and Employer of Choice for Technical professionals? Review of Public Administration, Vol. 25, No.3, pp. 225-242

[19] Mugenda, O. M. (1999). Research methods: Quantitative and qualitative approaches. African Centre for Technology Studies.

[20] National Public Procurement Integrity Baseline Survey [NPPIBS] Report (2006) (C) PPDA Authority, office of the Inspectorate of Government, \& the United State States Agency for International Development

[21] Ntayi, J. M., \& Eyaa, S. (2009). Supply chain swiftness in a developing country: The case of Uganda small and medium sized enterprises. E-Journal of Business and Economic Issues, 4(1), 2011-2014.

[22] Ntayi, J. M., Byabashaija, W., Eyaa, S., Ngoma, M., \& Muliira, A. (2010). Social cohesion, groupthink and ethical behavior of public procurement officers, Journal of public procurement, 10(1), 68

[23] Odhiambo, W., \& Kamau, P., (2003). Public procurement: Lessons from Kenya, Uganda and Tanzania (Vol. 208), Working Paper No.

[24] Oluka, P. N., \& Ssennoga, F., (2008). Tackling corruption in public procurement: A case of local governments in Uganda, In third International Public Procurement conference, Amsterdam.

[25] Public Procurement and Disposal of Public Assets Act [PPDA] (2003), Acts Supplement No. 1, The Uganda Gazette No. 3 Volume XCVII dated $17^{\text {th }}$ January, 2003. Printed by UPPC, Entebbe, by Order of the Government of Uganda

[26] Pujawan, I. N., (2004). Assessing supply chain flexibility: a conceptual framework and case study. International Journal of Integrated Supply Management, 1(1), 79-97.

[27] Sekaran, U., \& Bougie, R. Research Methods for Business: A Skill Building Approach. 2003. John Willey and Sons, New York.

[28] Sewanyana, L. (2009). Uganda, International Journal of Not-for-Profit L., Vol. 12, No. 78.

[29] Soreide, T. (2002). Corruption in public procurement. Causes, Consequences and Cures, CMI Report R, 1.

[30] Soudry, O., (2007). A principal-agent analysis of accountability in public procurement, Piga, $P$

[31] Strom, K. (2003) 'Parliamentary Democracy and Delegation', in K. Strom et al. (eds.) Delegation and Accountability in Parliamentary Democracies, Oxford: OUP, pp. 55-106.

[32] Tian, J., Arrowsmith, S., \& Trybus, M. (2003). Enforcement of procurement rules in China. Public Procurement: The Continuing Revolution, Kluwer Law International, The Netherlands.

[33] Thai, V. K., (2001). Public Procurement Re-Examined, Journal of Public Procurement, Vol. 1, Issue 1, pp. 9-50

[34] The Local Governments Act (2007), Chapter 243, (C) Government of Uganda. Available on: http://www.ulii.org/ug/legislation/consolidated-act/243

[35] Uganda Bureau of Statistics [UBOS] (2008). National Service Delivery Survey, (C) Uganda Bureau of Statistics, Statistics House, Colville Street, Kampala. Available on: http://www.ubos.org/onlinefiles/ uploads/ubos/pdf\%20documents/2008NSDSFinalReport.pdf

[36] Xia, W. \& Wu Z., (2007). Supplier selection with multiple criteria in volume discount environments, Omega, 35(5), 494-504

[37] Yuksel I, Dagdeviren M. 2007. Using the analytic network process (ANP) in aSWOT analysis - A case study for a textile firm. Information Sciences, 177, 3364-3382.

Citation: Peter W. Obanda, et.al. " Examining the Effects of Tactical Procurement Practices on Service Delivery" International Journal of Managerial Studies and Research (IJMSR), vol 7, no. 6, 2019, pp. 1-16. doi: http://dx.doi.org/10.20431/2349-0349.0706001.

Copyright: (C) 2019 Authors. This is an open-access article distributed under the terms of the Creative Commons Attribution License, which permits unrestricted use, distribution, and reproduction in any medium, provided the original author and source are credited. 